\title{
WHY I DIDN'T SET UP MY OWN BUSINESS
}

\author{
Idrus \\ Translated by A. L. Reber
}

I am an employee of the Indonesian "Import-Export" Company. My office is a newly painted garage. My desk is the size of a pocket handkerchief and my chair, an aged rocking chair.

When I come to the office in the morning, I open a cabinet-almost empty-and take out last month's newspapers and put them on my desk. All these are the acts of a man eager to start in on heaps of accumulated work. After this, I sit on that rocking chair and read the papers until my head droops onto my chest.

One time I even had a dream while asleep in that chair. It seemed to me that the Head Director of the company came.

"Why aren't you working?" said he, talking through his nose.

"Why do I have to work?" I answered.

"You're my employee, aren't you?" he responded.

"No," I replied, "I'm an angel."

Hearing this, he opened his wallet and gave me five hundred rupiah, while saying:

"Go back to being an ordinary human being," and he jumped into his sedan.

After two months of being treated like an angel-a being that doesn't need to eat or drink-one Sunday I was invited to the Company Director's home.

His house was beautiful and modern and located on a main road. The grounds were so large that my Director considered it necessary to have separate entrance and exit gates for

From "Mengapa Saya Ta' Jadi Dirikan Perusahaan Sendiri," Dengan Mata Terbuka (Kuala Lumpur: Pustaka Antara, 1961). The capitalization is the author's own. 
his car and the cars of cabinet ministers. That he was certain ministers of state would come to visit the house, he had mentioned to me one or two times.

Because I came on foot, I didn't have to worry about which was the entrance and which the exit to get to the house.

I was welcomed warmly by the Director of my firm and by two other people, a pretty woman who turned out to be his new wife, while the other, a man of middle age, happened to be the Vice President of a small bank.

After inviting me to sit down on a comfortable chair, my Director said:

"All of you probably already know about the new import regulations. Gentlemen, we have to pay forty percent in advance before we can import anything. Where can we get that kind of cash? Besides, it's certain that nobody wants to use his own money for such a purpose." Because the Director was looking at me, I felt obliged to offer my opinion. So I said:

"But these regulations absolutely don't apply to our company. ..."

I would have continued but my Director's face turned red with anger at my first sentence. So I just looked down at my shoes again and listened to his words, which seemed sure to be a reprimand.

"How can they not apply to our enterprise? We are an Import-Export Company, aren't we?" he said, laying special stress on the word 'import'.

After that, the Director did not look in my direction again. He talked on and on with the Vice President of the little bank, and finally reached an agreement that the bank Director would be appointed as a Director of our Import-Export Company.

Then, quite unexpectedly, my Director said to me:

"Beginning now, I appoint you as Deputy Director."

My face blanched, and it was only after I arrived home, that I realized that from that day on I had become a person of very great importance for the national economy.

Almost every day now, my Director came to the office. Each time he came, he asked me if there was a letter for him. And each day I had to spread my empty hands wide and shake my head regretfully.

But one day a letter really did come. Just as my Director's car stopped in front of the office, I waved the letter at him from inside the office. He jumped out of his car and like a small child snatched the letter from my hand. man:

With great attention, he opened the letter, read it, and suddenly he shouted like a mad

"Got it, got it."

From inside his car he still had time to yell to me:

"Come to the house tomorrow and get your pay."

And this was the first joy that I ever felt during my stint as Deputy Director.

Even though I only got one month's salary paid-or maybe he thought the 750 rupiah I received was pay for five months' work?-I began to have real hopes for this firm. The Director had been able to borrow four hundred thousand-because that was the total permitted by the credit bank. Now surely the Company would move ahead as it ought. 
In my imaginings, I received piles of letters each day from both inside the country and abroad. I happily sought tenders from overseas and gradually formed a staff of assistants.

But not one of these things actually happened. Our Import-Export Company didn't import or export anything at all, while the firm's Director never even stuck his nose inside the door. Eventually word came that my Director was buying rice fields and houses and land all over the place. From being the Director of a certain Company he had become a wellknown landlord.

As for me, I went back to being an angel. I had long since thrown away the necktie of a Deputy Director-who knows where - and each day, I did nothing but play chess with a friend of mine who happened to be out of work.

But since my friend couldn't tell castles from knights, he made the same moves with both, so that finally we stopped playing and just swapped stories all day long.

One day my friend said:

"You already have lots of experience in this Company. Why not set up one of your own? I can help you get credit from a bank. If you like, you can become Head Director and I'll be a member of the board. You'll be able to live in comfort and won't have to work here any more." I at once clasped my friend's hand and said earnestly:

"Yes, I agree. Try to arrange it," and the two of us danced for joy in the garage.

The next day my friend came again. Happily he told me that he had called on the Minister of Justice to explain why he was setting up a Company. The Minister of Justice agreed in principle, he said. But he needed one hundred rupiah to cover various expenses. And this one hundred rupiah had to come from me, he said.

But before he could finish, I interrupted and said:

"Apparently my Director found out about our plan to set up this new firm. Because yesterday he paid me two month's salary all at once."

"So you won't go on with setting up our Company?" asked my friend.

"Right now, there's no more reason to," I answered. "My Director promised to pay my salary regularly from now on."

"You don't have the guts," he said angrily. "And to hell with the guy who calls himself a Company Director but is afraid to compete with us."

I didn't say anything else and just looked at my shoes that were already getting holes in the toe. But meanwhile my friend's attitude had changed completely and like a man begging, he said:

"If you really got two months' pay, surely you won't mind lending me a hundred rupiah. We're in a real mess at home right now."

With some reluctance, I lent him twenty-five rupiah and in my heart of hearts, I hoped that with twenty-five rupiah as capital he would, with luck, be able to set up a Company that was $100 \%$ national. 
